Preface

\title{
Recent Developments in Antiphospholipid Antibodies and the Antiphospholipid Syndrome
}

\author{
Rolf T. Urbanus, $\mathrm{PhD}^{1}$ \\ ${ }^{1}$ Department of Clinical Chemistry and Haematology, University \\ Medical Center Utrecht, Utrecht University, Utrecht, \\ the Netherlands
}

Semin Thromb Hemost 2018;44:417-418.

This issue of Seminars in Thrombosis $\mathcal{E}$ Hemostasis is devoted to antiphospholipid (aPL) antibodies and the antiphospholipid syndrome (APS). aPL antibodies are well-recognized acquired risk factors for thrombosis and pregnancy-associated morbidity. They are the most common cause of acquired thrombophilia and are detected in up to $10 \%$ of patients with arterial or venous thrombosis. ${ }^{1}$ Patients with thrombosis or adverse pregnancy outcome in whom serological analysis has indicated the persistent presence of aPL are diagnosed with APS. This autoimmune disorder affects more women than men and is mostly diagnosed in patients younger than 50 years. $^{2}$ Although the incidence of thrombosis in the young is low, ${ }^{3-5}$ and APS should therefore be considered a rare disorder, aPL represents a significant health burden for society. Patients with APS are considered at increased risk for a recurrent thrombotic event. To prevent recurrence, they often receive life-long anticoagulant treatment, which is associated with a concomitant life-long risk of bleeding and requires frequent hospital visits.

The first description of a patient with aPL dates back almost seven decades. ${ }^{6}$ Since then, workers in the field have defined APS based on the collection of symptoms often found in patients with these antibodies, identified several aPL as serological markers of thrombotic disease, and have developed a means to classify patients with these antibodies into different categories as an aid in scientific research. ${ }^{7}$ Despite the progress that has been made, there is still much to learn about the pathophysiology of APS, the optimal treatment of patients with aPL, and the correct way to identify those patients at risk for a thrombotic event.

Being a rare disorder, not many clinical trials have been performed to systemically investigate treatment strategies in APS. Hence, there is limited available evidence to support the currently used treatment strategies for affected patients. Chighizola et al therefore provide, in this issue of Seminars in Thrombosis \& Hemostasis the latest insights in the management of thrombotic APS. ${ }^{8}$ Most patients with thrombotic APS

\footnotetext{
Address for correspondence Issue Theme Recent

Rolf T. Urbanus, PhD, Department Developments in

of Clinical Chemistry and Antiphospholipid Antibodies and

Haematology, University Medical the Antiphospholipid Syndrome;

Center Utrecht, Heidelberglaan Guest Editor: Rolf T. Urbanus,

100, Room G03.550, 3584 CX PhD.

Utrecht, the Netherlands

(e-mail: r.t.urbanus@umcutrecht.nl).
}

will receive vitamin $\mathrm{K}$ antagonists for secondary thromboprophylaxis. These broad spectrum anticoagulant drugs target the majority of the coagulation factors involved in hemostasis, and have been the drug of choice for decades, despite their association with clinically relevant bleeds and the need to frequently monitor drug efficacy using blood from treated patients. Nonvitamin K antagonist oral anticoagulants (NOACs), also called direct oral anticoagulants (DOACs), are small molecules that directly inhibit either active coagulation factor $\mathrm{X}$ or thrombin. NOACS are rapidly becoming the new standard for prevention of recurrent thrombosis due to their improved safety profile and lack of monitoring requirements. Whether or not NOACs are safe to use in APS, however, remains to be determined, and clinical trials that address this issue are currently under way. Cohen et al therefore report on the latest insights with respect to the use of NOACs in APS. ${ }^{9}$

Many different aPL have been described in patients with APS, but not all have been included in the official classification criteria $^{7}$ due to insufficient data that supported their inclusion. Nevertheless, laboratory diagnostics of APS include measurement of several serological markers, including anticardiolipin antibodies, anti- $\beta 2$-glycoprotein I antibodies, and lupus anticoagulant, leading to a complex laboratory array that should be performed on every eligible sample. Recent evidence suggests that the number of positive aPL in a patient determines the risk of a future event. Pengo et al address the diagnostic value of the aPL, as listed in the classification criteria, and discuss the added value of the presence of more than one of these antibodies in a single patient. ${ }^{10}$ Of the "criteria" aPL, we know the least about those antibodies that interfere with coagulation, the so-called lupus anticoagulants. Nevertheless, these antibodies correlate best with thrombosis and pregnancy morbidity in APS. Molhoek et al discuss the relevant paradoxical association between these in vitro coagulation inhibitors and thrombosis, and summarize what is known about their mode of action. ${ }^{11}$

Most physicians treating patients with APS will have encountered patients who do not fulfill the classification

Copyright $\odot 2018$ by Thieme Medical Publishers, Inc., 333 Seventh Avenue, New York, NY 10001, USA. Tel: +1(212) 584-4662.
DOI https://doi.org/ 10.1055/s-0038-1657761. ISSN 0094-6176. 
criteria due to the absence of the aPL currently listed in the classification criteria, ${ }^{7}$ but nevertheless present with classical features of APS, including thrombosis or pregnancy-associated morbidity and several of the noncriteria manifestations of APS, such as thrombocytopenia, or livedo reticularis. Accordingly, Bertolaccini and Sanna discuss the value of the noncriteria aPL in diagnostics of these "seronegative APS" patients and provide an overview of the available evidence that supports their use in risk assessment of APS patients. ${ }^{12}$ Antibodies against domain I of $\beta 2$-glycoprotein I are among these noncriteria aPL. Domain I of $\beta 2$-glycoprotein I has been reported to contain the dominant immunoepitope for pathology-associated aPL. ${ }^{13,14}$ Kelchtermans et al therefore provide an overview of studies on these antibodies and discuss their relevance for the pathophysiology of the syndrome, ${ }^{15}$ and Radin et al summarize the available evidence to support their use in the diagnostic workup of patients in a systematic review. ${ }^{16}$

How circulating aPL are linked to thrombosis and pregnancy-associated pathology remains a topic of investigation. Sacharidou et al therefore summarize the currently available data on the pathophysiology of APS. ${ }^{17}$ Evidence from in vitro studies and animal models support the notion that vascular cells are activated by the circulating aPL. Furthermore, MullerCalleja and Lackner provide an overview of the current insights in the way target cells are activated by aPL and discuss the data that support the role for the various cellular receptors that have been implicated in the pathophysiology of the syndrome. ${ }^{18}$

Our knowledge on extracellular vesicles, including microvesicles and exosomes, is ever increasing. They have been reported to transport ribonucleic acid (RNA) to other cells and to contain information about the cells they originate from. They have also been investigated in relation to APS. Accordingly, Chaturvedi et al discuss the value of extracellular vesicles as biomarkers for disease and their potential application in diagnostics of APS. ${ }^{19}$

With on average 500 new publications indexed in PubMed each year, aPL have the broad attention of a large scientific community. This special issue of Seminars in Thrombosis $\mathcal{E}$ Hemostasis provides an overview of currently available data on the treatment of patients with APS, laboratory diagnostics of aPL, and gives information on the current insights in the pathophysiological processes responsible the clinical manifestations of the syndrome. We hope that the reader finds this collection of articles on aPL timely, informative, and enjoyable. We sincerely thank all contributors for sharing their insights and wisdom and for their willingness to participate in this special issue.

\section{Conflicts of Interest}

None.

\section{References}

1 Andreoli L, Chighizola CB, Banzato A, Pons-Estel GJ, Ramire de Jesus G, Erkan D. Estimated frequency of antiphospholipid antibodies in patients with pregnancy morbidity, stroke, myocardial infarction, and deep vein thrombosis: a critical review of the literature. Arthritis Care Res (Hoboken) 2013;65(11):1869-1873
2 Cervera R, Piette JC, Font J, et al; Euro-Phospholipid Project Group. Antiphospholipid syndrome: clinical and immunologic manifestations and patterns of disease expression in a cohort of 1,000 patients. Arthritis Rheum 2002;46(04):1019-1027

3 Silverstein MD, Heit JA, Mohr DN, Petterson TM, O'Fallon WM, Melton LJ III. Trends in the incidence of deep vein thrombosis and pulmonary embolism: a 25-year population-based study. Arch Intern Med 1998;158(06):585-593

4 Rothwell PM, Coull AJ, Silver LE, et al; Oxford Vascular Study. Population-based study of event-rate, incidence, case fatality, and mortality for all acute vascular events in all arterial territories (Oxford Vascular Study). Lancet 2005;366(9499):1773-1783

5 Naess IA, Christiansen SC, Romundstad P, Cannegieter SC, Rosendaal FR, Hammerstrøm J. Incidence and mortality of venous thrombosis: a population-based study. J Thromb Haemost 2007;5(04):692-699

6 Conley CL, Hartmann RC. A hemorrhagic disorder caused by circulating anticoagulant in patients with disseminated lupus erythematosus. J Clin Invest 1952;31:621-622

7 Miyakis S, Lockshin MD, Atsumi T, et al. International consensus statement on an update of the classification criteria for definite antiphospholipid syndrome (APS). J Thromb Haemost 2006;4(02): 295-306

8 Chighizola CB, Raimondo MG, Meroni PL. Management of thrombotic antiphospholipid syndrome. Semin Thromb Hemost 2018; 44(05):419-426

9 Cohen H, Efthymiou M, Gates C, Isenberg D. Direct oral anticoagulants for thromboprophylaxis in patients with antiphospholipid syndrome. Semin Thromb Hemost 2018;44(05): 427-438

10 Pengo V, Bison E, Denas G, Jose SP, Zoppellaro G, Banzato A. Laboratory diagnostics of antiphospholipid syndrome. Semin Thromb Hemost 2018;44(05):439-444

11 Molhoek JE, de Groot PG, Urbanus RT. The lupus anticoagulant paradox. Semin Thromb Hemost 2018;44(05):445-452

12 Bertolaccini ML, Sanna G. The clinical relevance of noncriteria antiphospholipid antibodies. Semin Thromb Hemost 2018;44 (05):453-457

13 de Laat B, Derksen RH, Urbanus RT, de Groot PG. IgG antibodies that recognize epitope Gly40-Arg43 in domain I of beta 2glycoprotein I cause LAC, and their presence correlates strongly with thrombosis. Blood 2005;105(04):1540-1545

14 Ioannou Y, Romay-Penabad Z, Pericleous C, et al. In vivo inhibition of antiphospholipid antibody-induced pathogenicity utilizing the antigenic target peptide domain I of beta2-glycoprotein I: proof of concept. J Thromb Haemost 2009;7(05): 833-842

15 Kelchtermans H, Chayoua W, Laat B. The significance of antibodies against domain I of beta-2 glycoprotein I in antiphospholipid syndrome. Semin Thromb Hemost 2018;44(05): 458-465

16 Radin M, Cecchi I, Roccatello D, Meroni PL, Sciascia S. Prevalence and thrombotic risk assessment of anti-beta2 glycoprotein I domain I antibodies: a systematic review. Semin Thromb Hemost 2018;44(05):466-474

17 Sacharidou A, Shaul PW, Mineo C. New insights in the pathophysiology of antiphospholipid syndrome. Semin Thromb Hemost 2018;44(05):475-482

18 Muller-Calleja N, Lackner KJ. Mechanisms of cellular activation in the antiphospholipid syndrome. Semin Thromb Hemost 2018;44 (05):483-492

19 Chaturvedi S, Alluri R, McCrae KR. Extracellular vesicles in the antiphospholipid syndrome. Semin Thromb Hemost 2018;44 (05):493-504 